\title{
Penanganan Bencana Pohon Tumbang dalam Konteks Manajemen Perkotaan di Kabupaten Badung
}

\author{
Handling of Fallen Trees Disaster in the Context of Urban \\ Management in Badung Regency
}

\author{
Anak Agung Ngurah Aritama ${ }^{1, a)}$ \& I Made Agus Dharmadhiatmika ${ }^{2)}$ \\ 1) Program Studi Arsitektur, Universitas Warmadewa, Denpasar. \\ 2) Program Studi Arsitektur Pertamanan, Universitas Udayana, Denpasar.
}

Koresponden : a) gunkwah.aritama@gmail.com

\begin{abstract}
ABSTRAK
Potensi bencana pohon tumbang yang kerapkali terjadi di kawasan perkotaan menjadi topik yang dibahas pada penelitian ini. Sebagai kawasan dengan kepadatan yang cukup tinggi dengan populasi manusia yang ada di dalamnya, kawasan kota menjadi wilayah yang sangat rentan jika terjadi bencana. Potensi bencana pohon tumbang di lingkungan perkotaan dikategorikan cukup tinggi dikarenakan setiap tepi jalan di perkotaan selalu diisi oleh pohon perindang. Dalam penelitian ini akan dibahas strategi penanganan bencana pohon tumbang dalam konteks perencanaan dan manajemen perkotaan. Metode penelitian yang digunakan adalah kualitatif dengan pendekatan studi kasus yang dilakukan di Kabupaten Badung. Hasil penelitian menunjukkan terdapat tiga strategi dalam meminimalisir bencana pohon tumbang yakni perencanaan dan penempatan, pemeliharaan dan perawatan, terakhir pemangkasan dan pemotongan pohon.
\end{abstract}

Kata Kunci : manajemen fasilitas, bencana perkotaan, pohon tumbang, Kabupaten Badung.

\section{PENDAHULUAN}

Indonesia merupakan negara dengan potensi bencana yang cukup tinggi di dunia. Berdasarkan aspek potensi bencana (hazard potency) di Indonesia, maka aspek kebencanaan dapat dibagi menjadi dua yakni potensi bencana utama (main hazard) dan potensi bahaya ikutan (collateral hazard) (Anonim, 2002). Potensi bencana utama ini telah tertuang sebelumnya dalam peta-peta rawan bencana yang sebelumnya telah dirilis oleh pemerintah. Tidak kurang dari lima jenis bencana yang menjadi bencana utama di Indonesia.

Potensi bahaya ikutan (collateral hazard) pada aspek kebencanaan di Indonesia tidak kalah berbahayanya dengan bencana utama. Bencana ikutan merupakan bencana lanjutan yang terjadi akibat reaksi alam yang ditimbulkan oleh bencana utama. Beberapa jenis bencana ikutan yang kerap kali terjadi pada wilayah di Indonesia adalah banjir lahar, tsunami, likuifaksi, dan bencana pada kawasan perkotaan. Bencana pada kawasan perkotaan terjadi akibat kepadatan bangunan yang tinggi, bencana yang disebabkan keruntuhan dan lumpuhnya infrastruktur dan fasilitas kota. Berdasarkan fakta-fakta tersebut terbukti bahwa kawasan perkotaan juga tidak luput dari kerawanan bencana.

Kabupaten Badung sebagai salah satu daerah destinasi wisata unggulan di Provinsi Bali. Salah satu kegiatan pariwisatanya berpusat pada kawasan Badung Selatan yang termasuk ke dalam kawasan Metropolitan Sarbagita. Berbagai jenis dan bentuk bencana alam ternyata berpotensi terjadi di Kabupaten Badung. Berdasarkan Rencana Tata Ruang dan Wilayah 
Kabupaten Badung tahun 2013, terdapat berbagai macam potensi kebencanaan di Kabupaten Badung. Potensi bencana tersebut berupa angin kencang, kekeringan, banjir, tanah longsor, gempa bumi, dan tsunami.

Badung sebagai daerah dengan kondisi fisik pesisir yang cukup luas, menyimpan potensi bencana angin kencang. Kondisi tersebut diperkuat oleh peta daerah rawan bencana angin kencang yakni 7.098,03 ha atau kurang lebih 16.95\% dari total luas wilayah Kabupaten Badung. Selain potensi angin kencang, potensi bencana lainnya adalah terjadinya gelombang tsunami. Tercatat luas wilayah potensi bencana tsunami di Kabupaten Badung sebesar 1.561,77 ha yakni sebesar 3.7\% dari luas lahan di Kabupaten Badung Adapun Kecamatan Abiansemal tercatat sebagai wilayah dengan luasan wilayah rawan bencana terbesar dibandingkan dengan kecamatan lainnya (Anonim, 2013).

Tabel 1. Data Luasan Daerah Rawan Bencana di Kabupaten Badung

\begin{tabular}{|c|c|c|c|c|c|c|c|}
\hline \multirow[b]{2}{*}{$\begin{array}{c}\text { Jenis } \\
\text { Bencana }\end{array}$} & \multicolumn{6}{|c|}{ Luasan Daerah Rawan Bencana } & \multirow[b]{2}{*}{$\begin{array}{l}\text { Jml } \\
\text { (ha) }\end{array}$} \\
\hline & $\begin{array}{c}\text { Kuta } \\
\text { selatan }\end{array}$ & Kuta & Kuta Utara & Mengwi & $\begin{array}{c}\text { Abian } \\
\text { semal }\end{array}$ & Petang & \\
\hline $\begin{array}{c}\text { Angin } \\
\text { Kencang }\end{array}$ & $1.310,31$ & 951,57 & 978,75 & $1.849,14$ & $1.711,08$ & 297,18 & $7.098,03$ \\
\hline $\begin{array}{c}\text { Kekering } \\
\text { an }\end{array}$ & 11,07 & - & - & - & 0.09 & - & 11,6 \\
\hline Banjir & 752,49 & 951,57 & 251,91 & 58,77 & - & - & $2.011,59$ \\
\hline $\begin{array}{c}\text { Tanah } \\
\text { Longsor }\end{array}$ & 478,89 & - & 0,27 & 39,42 & 187,47 & $6.290,73$ & $6.996,78$ \\
\hline Gempa & - & - & - & 180,99 & 318,15 & 456,66 & 499,14 \\
\hline Tsunami & 556,02 & 931,86 & 63,27 & 10,62 & - & - & $1.561,77$ \\
\hline Jumlah & $3.108,78$ & $1.294,20$ & $185.203,80$ & $2.216,79$ & $7.044,57$ & 2.835 & \\
\hline
\end{tabular}

(Sumber: RTRW Badung 2013)

Data tersebut menunjukkan bahwa potensi bencana angin kencang yang terjadi Kabupaten Badung lebih tinggi daripada bencana lainnya. Lokasi bencana angin kencang dengan potensi sedang terletak pada wilayah Kecamatan Petang, Abiansemal, dan Mengwi. Sementara itu kawasan rawan bencana angin kencang potensi tinggi justru terjadi pada wilayah perkotaan yakni Kecamatan Kuta, Kuta Selatan, Kuta Utara, dan beberapa Kecamatan Mengwi dan Abiansemal. Kerawanan akibat bencana angin kencang ini membawa bahaya ikutan (collateral hazard) berupa bencana pohon tumbang dan lumpuhnya jaringan infrastruktur kota yang berada di ruang udara.

Potensi tingginya bencana pohon tumbang di kawasan perkotaan terutama di pinggir jalan utama seringkali terjadi terutama menjelang musim penghujan. Menurut sumber artikel media cetak, insiden terjadinya pohon tumbang di Kota Denpasar terjadi di sejumlah titik pada medio Desember 2017. Kejadian tersebut diantaranya adalah kejadian pohon tumbang di Jalan Raya Puputan, Jalan Hang Tuah, Jalan Kerta Dalem dan sejumlah titik di Kota Denpasar dan Badung (Putera, 2017). Namun dari keseluruhan kejadian tersebut tidak terdapat korban jiwa.

Potensi bencana berupa bahaya pohon tumbang ini merupakan bencana yang dapat diantisipasi sebelumnya. Antisipasi dapat dilakukan melalui manajemen pemeliharaan dan monitoring secara berkala terhadap perkembangan pohon. Monitoring terutama dapat dilakukan pada pohon perindang jalan yang keberadaannya diawasi oleh Dinas Lingkungan Hidup dan Kebersihan (DLHK). 
Pohon perkotaan harus dianggap sebagai fasilitas perkotaan yang penting. Oleh karena itu Pohon Perkotaan harus dikelola sesuai dengan prinsip Manajemen Aset Fasilitas. Manajemen Aset Fasilitas pada dasarnya adalah teori dan tindakan untuk mengelola fasilitas, agar fasilitas bisa selalu berfungsi dengan baik secara ekonomis, efisien, efektif dan semua resiko terkait sudah diperhitungkan (Soemitro \& Suprayitno 2018).

Guna mengantisipasi permasalahan tersebut diperlukan suatu manajemen dalam konteks urban manajemen yang dapat memantau secara menyeluruh keberadaan pohon perindang jalan. Artikel ini memaparkan keberadaan manajemen penanganan pohon tumbang dalam konteks manajemen mitigasi bencana perkotaan.

\section{TINJAUAN LITERATUR}

Konstruksi Bencana merupakan rangkaian peristiwa atau peristiwa yang dapat mengganggu dan membahayakan kehidupan manusia dan masyarakat. Bahaya tersebut baik ditimbulkan oleh faktor alam maupun faktor non alam maupun oleh faktor manusia sendiri sehingga mengakibatkan kerugian baik korban jiwa manusia, harta benda, maupun dampak ikutannya seperti wabah penyakit dan psikologi (Anonim, 2007).

Penanggulangan dan antisipasi bencana yang sering disebut dengan mitigasi bencana seringkali digaungkan sebagai sesuatu yang sangat penting dilakukan. Berkali-kali bencana terjadi dan yang selalu berulang adalah penanggulangan baru dilakukan pada saat setelah/pasca terjadinya bencana. Pada peristiwa dan insiden bencana perkotaan kerapkali pemerintah dan masyarakat gagap menghadapi bencana yang harusnya dapat diantisipasi sebelumnya.

Tren bencana global memiliki kecenderungan peningkatan pada beberapa tahun terakhir. Beberapa faktor yang mempengaruhi peningkatan bencana global antara laian adalah: 1) Meningkatnya jumlah penduduk, 2) Urbanisasi, 3) Degradasi lingkungan, 4) Kemiskinan, dan 5) Pengaruh perubahan iklim global (Brophy, 2000). Salah satu bencana yang disebabkan oleh perubahan iklim global adalah tidak menentunya iklim global yang mengakibatkan munculnya bencana angin kencang secara tiba-tiba.

Pada lingkungan perkotaan pengaruh yang dirasakan akibat dari tren meningkatnya bencana global yang kerapkali dirasakan adalah meningkatnya bencana banjir, angin kencang, dan peningkatan suhu udara di lingkungan ruang kota. Selain itu pengaruh bencana tidak hanya berdampak pada lingkungan perkotaan semata, bahkan bencana juga akan mempengaruhi lingkungan sosial dan ekonomi masyarakat, mengingat potensi wilayah perkotaan sebagai penggerak ekonomi wilayah di sekitarnya. Salah satu contoh kecil bencana yang diangkat dalam artikel ini adalah bencana pohon tumbang. Bencana pohon tumbang di pinggir jalan perkotaan tentunya akan mengganggu lalu lintas di perkotaan dan berpengaruh pada kelancaran distribusi barang dan jasa.

Mengatasi permasalahan tersebut diperlukan upaya mitigasi bencana yang bertitik tolak pada penanganan manajemen yang berbasis manajemen perkotaan. Mitigasi dapat diartikan sebagai kegiatan penjinakan/peredaman, yaitu melalui peredaman untuk mengurangi atau bahkan dapat meniadakan korban yang ditimbulkan akibat bencana. Mitigasi bencana dilakukan untuk memperlunak dan memperkecil dampak yang ditimbulkan oleh bencana (Anonim, 2002).

Kebijakan mitigasi bencana perkotaan selain memiliki kompleksitas dalam penanganan bencana juga sebagai pedoman dan arahan kebijakan pra bencana. Sebagai panduan kebijakan pra bencana, mitigasi bencana perkotaan juga berperan untuk menyiapkan masyarakat untuk dapat "membiasakan diri" untuk menghadapi bencana. Khususnya bagi masyarakat yang sudah bermukim di lingkungan kota yang sudah terlanjur terbangun, melalui pengembangan sistem peringatan dini dan pedoman bersama menghadapi bencana. Dalam hal ini masyarakat 
tidak hanya menjadi korban ketika terjadinya bencana, tetapi juga masyarakat berperan sebagai agen yang dapat memonitoring serta berperan aktif ketika pra dan pasca bencana.

Upaya yang dilakukan untuk dapat menyiapkan masyarakat agar dapat "membiasakan diri" dalam menghadapi bencana yakni melalui tahapan manajemen kesiapsiagaan bencana. Tahapan kesiapsiagaan pada bencana dapat diperlihatkan pada gambar berikut ini.

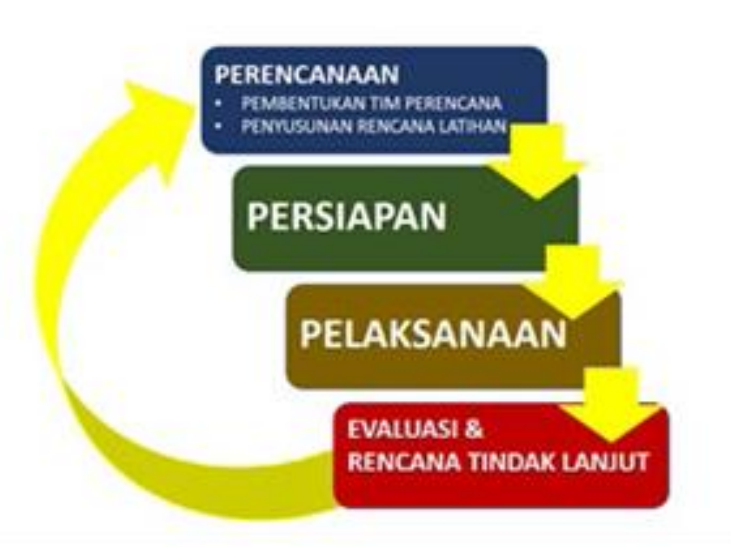

Gambar 2. Tahapan Kesiapsiagaan Bencana

(Sumber: Pedoman Kesiapsiagaan Bencana Nasional)

Dalam penanggulangan bencana diperlukan empat tahapan antara lain: tahap perencanaan, persiapan, pelaksanaan, evaluasi dan rencana tindak lanjut. Pada aspek bencana perkotaan khususnya penanganan bencana pohon tumbang tahapan perencanaan meliputi penentuan resiko dan ancaman titik dan lokasi potensi terjadinya pohon tumbang. Selanjutnya pada tahap perencanaan disusun standar operasional dan prosedur ketika terjadi bencana pohon tumbang.

Selanjutnya pada tahapan persiapan dilakukan briefing-briefing sehingga dapat mematangkan rencana sebelumnya. Pada tahap persiapan juga disiapkan peta lokasi dan jalur pengalihan jalur jalan jika suatu saat terjadi bencana. Tahapan selanjutnya adalah pelaksanaan, pada tahapan pelaksanaan dilakukan segala hal yang terjadi pada saat terjadinya bencana, yakni reaksi terhadap terjadinya bencana pohon tumbang, kecermatan dan kesigapan menjadi kunci pada tahapan pelaksanaan.

Setelah segala hal teratasi selanjutnya dilakukan proses dokumentasi, untuk dapat merekam segala hal dalam proses reaksi cepat penanganan bencana. Terakhir adalah evaluasi dan rencana tindak lanjut. Segala macam proses yang telah dilakukan dalam penanganan bencana pohon tumbang dianalisis. Selanjutnya dilakukan evaluasi melalui data dan dokumentasi hasil reaksi penanganan bencana pohon tumbang. Hal ini dilakukan untuk dapat memperbaiki hal yang kurang tepat dalam reaksi penanganan bencana sehingga terjadi peningkatan kualitas penanganan bencana di masa yang akan datang.

\section{METODOLOGI PENELITIAN}

Metode Penulisan artikel ilmiah Penanganan Bencana Pohon Tumbang Dalam Konteks Manajemen Perkotaan di Kabupaten Badung menggunakan metode kualitatif dengan pendekatan studi kasus. Studi kasus dilakukan pada satu isu dan persoalan yakni manajemen penanganan bencana pohon tumbang.

Teknik pemilihan sampel pada penelitian menggunakan purposive sampling. Pemilihan sampel pada penelitian dilakukan pada objek-objek penting dengan fokus kajian pada manajemen dan strategi mitigasi bencana perkotaan. Lokasi penelitian dilaksanakan di Dinas 
Lingkungan Hidup dan Kebersihan Kabupaten Badung, sub bidang Tanaman dan Penghijauan, pada November 2018 hingga Desember 2018.

\section{HASIL DAN DISKUSI}

\section{Strategi Dan Manajemen Bencana Perkotaan}

Munculnya bencana di kawasan perkotaan menjadi perhatian serius tatkala kepadatan penduduk di kawasan perkotaan yang cukup tinggi ditambah dengan pertumbuhan penduduknya yang cukup tinggi. Tingginya pertumbuhan penduduk menyebabkan permintaan yang tinggi pula pada lahan baik untuk perumahan maupun industri. Hal tersebut juga berbanding lurus terhadap peningkatan potensi kerentanan terkena bencana. Melalui pertambahan areal permukiman dan industri potensi tersebut sejalan dengan bertambahnya area yang potensial terhadap bencana.

Tingginya pertambahan penduduk di wilayah perkotaan tidak hanya disebabkan oleh pertumbuhan penduduk alamiah namun juga melalui proses urbanisasi. Tingginya angka urbanisasi juga secara tidak langsung merupakan 'bencana' pada skala perkotaan. Karena hal ini jelas akan menjadikan lingkungan perkotaan sebagai ruang 'perebutan' sumber-sumber daya antara penduduk asli dengan penduduk urban. Untuk itu diperlukan penanganan dan kebijakan mitigasi bencana perkotaan diantaranya adalah :

a. Mengurangi resiko/dampak yang ditimbulkan oleh bencana khususnya bagi penduduk perkotaan, seperti korban jiwa (kematian), kerugian ekonomi (economy costs) dan kerusakan sumber daya alam.

b. Sebagai landasan (pedoman) untuk perencanaan pembangunan perkotaan.

c. Meningkatkan pengetahuan masyarakat perkotaan (public awareness) dalam menghadapi serta mengurangi dampak/resiko bencana, sehingga masyarakat dapat hidup dan bekerja dengan aman (safe) (Anonim, 2002).

Berdasarkan Arahan Kebijakan Nasional Mitigasi Bencana Perkotaan terdapat beberapa jenis bencana yang merupakan bagian dari ancaman bahaya terhadap kawasan perkotaan. Bencana yang dimaksud secara garis besar dapat digolongkan dalam tiga kategori yakni bencana alam, bencana non alam, dan bencana sosial. Berdasarkan jenis dan tingkat ancaman bahaya pada lingkungan perkotaan bencana dapat dibagi menjadi beberapa jenis, antara lain (Priatmodjo, 2011) :

a. Gempa Bumi

Gempa bumi terjadi diakibatkan pelepasan energi yang berakibat pada bergesernya lapisan-lapisan bumi. Penyebabnya adalah proses tektonik (pergeseran lempeng bumi), vulkanik (letusan gunung api), atau ledakan nuklir. Ancaman bahaya gempa bumi bagi lingkungan perkotaan adalah robohnya bangunan, infrastruktur, kebakaran, yang dapat membahayakan manusia yang ada di dalamnya.

Bencana gempa bumi juga membawa dampak ikutan terhadap lingkungan perkotaan. Dampak ikutan yang ditimbulkan antara lain bahaya tanah longsor, banjir, kebakaran akibat hubungan pendek listrik, kecelakaan transportasi dan kecelakaan industri. Dampak ikutan yang paling dahsyat yakni terjadinya gelombang tsunami. Dampak bahaya gempa bumi bagi lingkungan perkotaan berpengaruh besar pada kondisi masyarakat urban.

b. Tsunami

Tsunami adalah gelombang laut dengan periode panjang yang ditimbulkan oleh gangguan impulsif dari dasar laut. Gangguan impulsif bisa disebabkan oleh gempa bumi dengan dislokasi masa tanah/batuan besar di bawah air (laut/danau); tanah longsor di dalam laut; serta letusan gunung api di bawah laut atau gunung api pulau. Kata "tsunami" berasal dari bahasa Jepang. 
c. Banjir

Banjir adalah kondisi di mana suatu wilayah dalam keadaan tergenang oleh air dalam jumlah yang besar. Penyebab banjir adalah curah hujan yang tinggi; gelontoran air hujan yang tidak terserap di wilayah hulu (karena terjadi penggundulan hutan); sungaisungai yang mengalami penyempitan atau pendangkalan (karena sampah dan pembangunan tidak terkendali di sekitarnya), atau kondisi topografis berupa cekungan yang cenderung menjadi daerah pengumpulan air.

d. Gelombang

Gelombang pasang adalah gelombang air laut di atas batas normal (kecepatan 10-100 $\mathrm{km} / \mathrm{jam}$ ) yang dapat menimbulkan bahaya baik di lautan, maupun di darat terutama daerah pinggir pantai. Gelombang pasang terjadi karena adanya angin topan, perubahan cuaca yang sangat cepat, dan karena pengaruh gravitasi bulan atau matahari.

e. Angin Topan

Angin topan adalah pusaran angin kencang dengan kecepatan $120 \mathrm{~km} / \mathrm{jam}$ atau lebih yang sering terjadi di wilayah tropis di antara garis balik utara dan selatan, kecuali di daerah-daerah yang sangat berdekatan dengan Khatulistiwa. Angin topan disebabkan oleh perbedaan tekanan dalam suatu sistem cuaca, dan bisa berpusar sampai radius ratusan kilometer. Di Indonesia angin topan dikenal dengan sebutan angin badai atau putting beliung.

Ancaman bahaya angin topan adalah kerusakan bangunan, roboh tertimpa atau tersapu angin, manusia tertimpa bangunan, dan pohon yang tumbang.

\section{Manajemen Penanggulangan Bencana Pohon Tumbang, Mitigasi dan Penanganan Bencana}

Penghijauan merupakan salah satu program penting untuk menjaga keberlangsungan ekosistem di lingkungan perkotaan. Berbagai macam jenis vegetasi terdapat menjadi vegetasi dalam penghijauan perkotaan. Selain menjaga keberlangsungan ekosistem, pohon juga memiliki potensi bencana yang cukup besar.

Sering terdengar di berbagai media kejadian pohon tumbang yang terjadi terutama di wilayah perkotaan. Terjadinya bencana pohon tumbang ini seringkali sebagai akibat dari pasca bencana angin topan. Efek dari angin topan tersebut membuat batang, ranting, dan dahan pohon yang tidak kuat menjadi patah sehingga menimpa benda yang berada di sekelilingnya.

Tidak hanya terjadi akibat angin topan, kejadian pohon tumbang juga terjadi akibat dari pelapukan bagian-bagian pohon yang telah berusia tua. Kerusakan bagian-bagian pohon yang telah tua tersebut selayaknya dapat dideteksi lebih dini, agar dapat menghindarkan terjadinya musibah (Sulistyantara, 2014).

Selain menimpa benda yang berada di sekelilingnya tidak jarang perisitiwa pohon tumbang sampai memakan korban jiwa. Hal tersebut dikarenakan posisi pohon yang tumbang berada pada ruang-ruang publik yang sehari-harinya dilewati oleh masyarakat. Berbagai macam kerugian tercatat ditimbulkan akibat perisitiwa pohon tumbang selain korban nyawa, pohon tumbang dapat merusak sarana dan prasarana infrastruktur kota.

Dalam manajemen dan perencanaan kota kerapkali terdapat kelalaian dalam mengantisipasi hal tersebut. Sudah saatnya seluruh kalangan baik masyarakat, pemerintah, maupun berbagai ahli dan akademisi untuk dapat sadar dan memiliki perhatian kepada salah satu bencana ini. Untuk itu diperlukan pencegahan dan mitigasi agar dapat menghindarkan terjadinya peristiwa tersebut.

Terdapat beberapa penyebab terjadinya kerusakan dan gangguan pada pohon hingga tumbang di lingkungan perkotaan, menurut Sulistyantara (2014) antara lain adalah : 
a. Pemilihan jenis pohon yang tidak sesuai dengan kondisi lingkungan penanaman, sehingga pertumbuhannya tidak sesuai yang diharapkan dan cenderung mati.

b. Desain dan perencanaan titik pohon yang salah, kesalahan dalam penempatan pohon yang tidak sesuai dengan skalanya dapat mencederai pohon tersebut.

c. Kegiatan vandalisme yang merusak, perilaku masyarakat yang dengan sengaja merusak dan mencederai pohon antara lain dengan memaku batang pohon, menyadarkan dengan beban yang berat, dan menyayat kulit batang pohon dapat merusak kesehatan pohon dan berpotensi merusak pohon.

d. Kondisi polusi lingkungan, tingkat polusi yang tinggi di tengah kota berpotensi menyebabkan gangguan kesehatan pada pohon dan menyebabkan gangguan perkembangan pohon.

e. Pemeliharaan dan manajemen perawatan yang seadanya. Perawatan dan manajemen perawatan pohon yang tidak optimal bahkan cenderung pohon perindang jalan hanya disiram ketika musim hujan.

Melihat pada aspek-aspek yang menyebabkan terjadinya pohon tumbang tersebut, dalam aspek manajemen dan perencanaan terdapat beberapa hal yang dapat dilakukan agar dapat meminimalisir kejadian tersebut, beberapa diantaranya adalah :

a. Perencanaan dan penempatan pohon perindang harus dilaksanakan dengan analisis dan pemilihan yang tepat, sehingga pertumbuhan pohon optimal dan meminimalisir terjadinya gangguan pertumbuhan.

b. Pemeliharaan dan perawatan yang dilakukan secara berkala, baik yang dilakukan secara oleh sub Dinas terkait maupun oleh masyarakat. Masyarakat seyogianya dapat memberikan laporan terkait, jika menemukan kerusakan pohon perindang.

c. Pemangkasan dan pemotongan yang dilakukan secara berkala untuk menjamin pertumbuhan pohon pada arah yang diharapkan.

\section{Manajemen Pemeliharaan Pohon Perindang di Kabupaten Badung}

Perencanaan dan manajemen pemeliharaan pohon perindang di Kabupaten Badung dilaksanakan oleh Dinas Lingkungan Hidup dan Kebersihan, yakni secara khusus ditangani oleh Seksi Tanaman dan Penghijauan. Berdasarkan hasil survey hingga tahun 2018 tercatat terdapat 52.325 titik pohon perindang yang tersebar di sepanjang 265.037 meter ruas jalan di Kabupaten Badung. Dari keseluruhan pohon yang sudah tertanam tersebut terdapat beberapa jenis pohon antara lain: Angsana, Glodok, Mahoni, Trembesi, Tabebuya, Waru, Ketapang, Dadap, dan Sawo Kecik.

Berikut dibawah ini akan disajikan data mengenai pohon perindang di Kabupaten Badung pada tahun 2016.

Tabel 2. Jumlah dan Jenis Pohon Perindang di Kabupaten Badung tahun 2016

\begin{tabular}{|c|c|c|c|c|}
\hline No & Kecamatan & $\begin{array}{c}\text { Panjang } \\
\text { Jalan } \\
(\mathbf{m})\end{array}$ & $\begin{array}{c}\text { Jumlah } \\
\text { Pohon yang } \\
\text { Tertanam } \\
\text { (unit) }\end{array}$ & $\begin{array}{c}\text { Jenis } \\
\text { Pohon }\end{array}$ \\
\hline 1 & Petang & 22.287 & 2.522 & $\begin{array}{c}\text { Angsana, } \\
\text { Glodok, } \\
\text { Mahoni, } \\
\text { Trembesi, } \\
\text { Tabebuya }\end{array}$ \\
\hline 2 & Abiansemal & 70.290 & 6.653 & $\begin{array}{c}\text { Angsana, } \\
\text { Glodok, } \\
\text { Mahoni, }\end{array}$ \\
\hline
\end{tabular}




\begin{tabular}{|c|c|c|c|c|}
\hline No & Kecamatan & $\begin{array}{c}\text { Panjang } \\
\text { Jalan } \\
\text { (m) }\end{array}$ & $\begin{array}{c}\text { Jumlah } \\
\text { Pohon yang } \\
\text { Tertanam } \\
\text { (unit) }\end{array}$ & $\begin{array}{l}\text { Jenis } \\
\text { Pohon }\end{array}$ \\
\hline & & & & Trembesi \\
\hline 3 & Mengwi & 62.745 & 5.366 & $\begin{array}{c}\text { Angsana, } \\
\text { Glodok, } \\
\text { Mahoni, } \\
\text { Trembesi, } \\
\text { Tabebuya, } \\
\text { Spatodea, } \\
\text { Kupu-kupu, } \\
\text { Waru }\end{array}$ \\
\hline 4 & Kuta Utara & 46045 & 3.854 & $\begin{array}{c}\text { Angsana, } \\
\text { Glodok, } \\
\text { Mahoni, } \\
\text { Trembesi, } \\
\text { Ketapang, } \\
\text { Dadap } \\
\text { Merah }\end{array}$ \\
\hline 5 & Kuta & 41.448 & 8.249 & $\begin{array}{c}\text { Angsana, } \\
\text { Glodok, } \\
\text { Mahoni, } \\
\text { Trembesi, } \\
\text { Tabebuya, } \\
\text { Kupu-kupu, } \\
\text { Waru }\end{array}$ \\
\hline 6 & $\begin{array}{l}\text { Kuta } \\
\text { Selatan }\end{array}$ & 18.810 & 2.384 & $\begin{array}{c}\text { Angsana, } \\
\text { Glodok, } \\
\text { Mahoni, } \\
\text { Trembesi, } \\
\text { Ketapang }\end{array}$ \\
\hline
\end{tabular}

(Sumber: DLHK Kabupaten Badung 2018)

Banyak dan beragamnya jenis pohon perindang dan pohon lainnya yang berada pada lahan-lahan masyarakat dan tanah negara, kondisi ini menuntut penanganan dan manajemen pengelolaan dalam mengatasi kondisi tersebut. Dalam menangani pemeliharaan dan perawatan pohon perindang tersebut dilaksanakan pemangkasan rutin yang dilakukan oleh Divisi Pemangkasan. Terdapat dua macam strategi dalam melaksanakan kegiatan pemangkasan pohon di Kabupaten Badung.

a. Pemangkasan yang dilakukan secara berkala, sebelum dilakukan pemangkasan dilaksanakan survey untuk memetakan potensi pohon perindang yang sudah lebat. Pertimbangan lainnya dalam pelaksanaan pemangkasan pohon adalah adanya potensi gangguan akibat cuaca buruk dan iklim. Sehingga diantisipasi melalui pemangkasan pohon. Pertimbangan lainnya adalah kedekatan potensi lokasi dengan wilayah kota dan kawasan pariwisata.

b. Pemangkasan pohon dapat dilakukan atas permintaan dari masyarakat sendiri. Pemangkasan biasanya dilakukan melalui prosedur bersurat secara resmi kepada DLHK Kabupaten Badung yang nantinya akan ditanggapi secara resmi juga. Permintaan pemangkasan biasanya dilakukan atas pertimbangan umur pohon, pertimbangan potensi bahaya terhadap lingkungan di sekitarnya, dan keberadaan pohon yang mengganggu visual dan fisik bangunan.

c. Pelaksanaan pemangkasan dan pemeliharaan pohon dilaksanakan pada hari kerja dari pagi hingga selesai pemotongan disesuaikan dengan kondisi lapangan agar tidak mengganggu kondisi masyarakat dan lalu lintas di sekitarnya. 


\section{KESIMPULAN}

Tingginya potensi bencana pohon tumbang di kawasan Perkotaan menjadi isu yang belum banyak dibahas. Bencana pohon tumbang dapat dikategorikan sebagai bencana utama maupun bencana ikutan. Penyebab terjadinya pohon tumbang tidak hanya oleh angin topan atau puting beliung, pohon dapat tumbang juga dikarenakan pohon itu sendiri baik akibat umur yang sudah tua, pelapukan bagian dalam batang, maupun gangguan kesehatan baik akibat kesalahan penempatan maupun vandalisme.

Guna meminimalisir potensi terjadinya pohon tumbang diperlukan mitigasi bencana dalam skala perkotaan yang dilaksanakan oleh pemerintah kota. Terdapat beberapa cara dan strategi yang dapat dilakukan untuk dapat meminimalisir potensi terjadinya bencana antara lain adalah: Pertama perencanaan dan penempatan titik penanaman pohon melalui analisis keadaan; Kedua adalah pemeliharaan dan perawatan pohon baik dilakukan oleh pemerintah maupun melalui pengawasan masyarakat; Ketiga melalui pemangkasan dan pemotongan pohon secara berkala.

\section{DAFTAR PUSTAKA}

Anonim. (2002). Arahan Kebijakan Mitigasi Bencana Perkotaan di Indonesia. Badan Koordinasi Nasional Penanggulangan Bencana dan Penanganan Pengungsi, Jakarta

Anonim. (2016). "Pemerintah Kota Denpasar". Retrieved Maret 1, 2018, from Profil Denpasar:https://denpasarkota.go.id/assets_subdomain/CKImages/files/kelamin-16.jpg.

Anonim. (2013). RTRW Kabupaten Badung Tahun 2013-2033. Bappeda Kabupaten Badung, Mangupura.

UU 24/07. Undang Undang RI No 24 Tahun 2007 tentang Penanggulangan Bencana.

Brophy, V. D. (2000). Sustainable Urban Design. Energi. Dublin.

Priatmodjo, D. (2011). Penataan Kota Bermuatan Antisipasi Bencana. Jurnal Nalars, Vol. 10, No. 2, Juli 2011, Hal: 83-104

Putera, A. (2017). "Hujan Dua Hari, Denpasar Dilanda Pohon Tumbang dan Genangan". Retrieved Oktober 10, 2018, from Balipost Portal Berita: htttp://balipost.com.

Soemitro, R.A.A. \& Suprayitno, H. (2018). "Pemikiran Awal tentang Konsep Dasar Manajemen Aset Fasilitas". Jurnal Manajemen Aset \& Fasilitas, Vol. 2, Sup. 1, Juni 2018, Hal. :1-13.

Sulistyantara, B. (2014). "Upaya Menurunkan Resiko Pohon Tumbang”, Risalah Kebijakan Pertanian dan Lingkungan, Departemen Arsitektur Lanskap Institut Pertanian Bogor Vol. 1, No. 1, April 2014, Hal: 7-11. 
(e)ISSN 2615-1847 (p)ISSN 2615-1839

Jurnal Manajemen Aset Infrastruktur \& Fasilitas - Vol. 3, Edisi Khusus 1, Maret 2019 